\title{
Culture and Molecular Identification of Helicobacter pylori in Drinking Water from Areas of High and Low Incidence of Gastric Cancer in Costa Rica
}

\author{
Virginia Montero Campos ${ }^{1}$, Alejandro Hernández Soto ${ }^{2}$, Jorge Camacho Sandoval ${ }^{3}$ \\ ${ }^{1}$ Instituto Tecnológico de Costa Rica, Research \& Chemical and Microbiology Services Center-CEQIATEC, \\ Cartago, Costa Rica \\ ${ }^{2}$ Instituto Tecnológico de Costa Rica, Biotechnology Research Center, Cartago, Costa Rica \\ ${ }^{3}$ Doctorate in Natural Sciences for Development, DOCINADE, Cartago, Costa Rica \\ Email: vmontero@itcr.ac.cr, vmonterocampos@gmail.com
}

Received 15 November 2014; revised 6 December 2014; accepted 20 December 2014

Copyright (C) 2014 by authors and Scientific Research Publishing Inc.

This work is licensed under the Creative Commons Attribution International License (CC BY). http://creativecommons.org/licenses/by/4.0/

(c) (i) Open Access

\begin{abstract}
Background: Most patients infected with Helicobacter pylori show no clinical symptoms. Nonetheless, approximately $10 \%$ to $20 \%$ of these patients will develop peptic ulcers and $1 \%$ will develop gastric cancer. The International Agency for Cancer Research has classified Helicobacter pylori as a Group 1 carcinogen. Materials and Methods: Drinking water samples from 20 cantons situated in areas of low and high incidence of gastric cancer in Costa Rica were analyzed. Water samples were concentrated and the nitrocellulose filter was cultivated for later molecular identification of Helicobacter pylori using the gImM marker. The tumor necrosis factor-alpha inducing protein (Tipalpha TNF- $\alpha$ ) was used as a pathogenicity marker of the strains found followed by the sequencing of two products. Information on water management by aqueduct operators was collected in order to establish statistical relationships. Results: A total of 112 water samples were analyzed. Successful cultivation and molecular identification using the $\operatorname{gIm} M$ marker was achieved in $39 \%$ of samples from areas of high incidence and in $7.5 \%$ of samples from areas of low incidence. Two $\mathrm{glmM}$ gene PCR products were sequenced and confirmed as true positives. Conclusions: The highest prevalence rate of Helicobacter pylori was found in water from areas with a high incidence of gastric cancer. Additionally, significant statistical correlations were established among environmental conditions, drinking water management and incidence of gastric cancer.
\end{abstract}

\section{Keywords}

Helicobacter pylori, Cancer Gastric, Drinking Water, gImM Marker

How to cite this paper: Campos, V.M., Soto, A.H. and Sandoval, J.C. (2014) Culture and Molecular Identification of Helicobacter pylori in Drinking Water from Areas of High and Low Incidence of Gastric Cancer in Costa Rica. Open Journal of Medical Microbiology, 4, 261-269. http://dx.doi.org/10.4236/ojmm.2014.44030 


\section{Introduction}

Chronic infection with $H$. pylori in the human stomach can last decades resulting in persistent inflammation. Worldwide, the condition caused by Helicobacter pylori infection is the most common infectious disease affecting humans and an estimated $50 \%$ of the human population is infected [1]. This condition can lead to persistent gastritis and is directly related to the development of peptic ulcers, gastric adenocarcinoma and lymphoma of the stomach's mucous membrane [1].

According to the American Cancer Society [2], long-term infection with Helicobacter pylori is classified as a risk factor for gastric cancer. The latter is believed to be due to biological factors such as bacterial virulence factors, levels of pepsinogens and polymorphisms in humans [3].

According to an updated review March 2012, the World Health Organization's International Agency for Cancer Research (IACR) [4] has classified infection with Helicobacter pylori as a Group 1 carcinogen. In other words, there is sufficient evidence to consider it a carcinogen in humans and it is currently the only bacteria in this group. Other microorganisms included in this group of toxic biological carcinogens are the Hepatitis B and C Viruses and infection with Human Immunodefficiency Virus type 1.

Helicobacter pylori infection in humans and its relationship with cancer is attributed to two main modes of action. In the first mode of action, several oncogenic routes are activated such as protein-1 activator, NF-kB, Wnt $/ \beta$-catenin, signal transducers and activators of transcription 3, P13K and cyclooxygenase- 2 and all contribute to the process of oncogenic transformation [5]. Additionally, bacterial virulence factors such as cytosine associated with antigen A and the cag pathogenicity island are key mediators of inflammation and activation of oncogenic routes [5].

In the second mode of action, Helicobacter pylori induces epigenetic alteration, which refers to the study of all those non-genetic factors intervening in the hereditary regulation of gene expression with absence of changes in nucleotide sequencing. Said alteration mainly includes DNA methylation and histone deacetylation or methylation and interaction with stem cells.

Worldwide, Costa Rica ranks ninth in incidence of gastric cancer (IGC) per capita [6]. Despite the fact that the worldwide rate of Helicobacter pylori infection and incidence of gastric cancer are declining, gastric cancer is still the second most common cause of cancer-related death in Costa Rica and worldwide as a result of delayed diagnosis [6].

The incidence of gastric cancer in Costa Rica is extremely heterogenous and can differ up to sixfold from one canton to another in a country with a total surface area of $51,060 \mathrm{Km}^{2}$ and a population of approximately 4,500,000 inhabitants. The information on IGC collected from 1970 to date, according to the National Tumor Registry [7] reveals a higher IGC in the country's central mountain region, while the low coastal regions have a significantly lower IGC. More than $60 \%$ of the Costa Rican population live in the mountain regions making this a serious sanitary concern.

In view of the high incidence of gastric cancer in the country and its potential relationship with Helicobacter pylori, the objective of this study was to determine the presence of this bacteria in sources of drinking water in areas of high and low incidence of gastric cancer in Costa Rica.

\section{Methods}

Standardization of cultivation and molecular biology techniques was done using Hp 51932 and Hp 700392 reference strains from the American Type Culture Collection, as well as DNA from the Helicobacter pylori strain 12455 from the National Collection of Type Cultures NCTC and strain J99 [8].

Sampling areas were selected based on data from Costa Rica's National Tumor Registry on cantons with a high and low incidence of gastric cancer. Drinking water samples were obtained from 10 cantons with high incidence of gastric cancer (incidence rates per 100,000 inhabitants between 68.57 and 34.58) and these were the Central Canton of Cartago, Aserri, Paraiso, Santa Maria de Dota, San Pablo de Leon Cortez, Tarrazu, Tejardel Guarco, Alvarado, Oreamuno and Acosta. The low incidence areas of gastric cancer chosen (incidence rates per 100,000 inhabitants ranged between 18.97 and 9.80) were the cantons of Nicoya, Santa Cruz, Los Chiles, La Cruz, Liberia, Tilaran, Nandayure, San Mateo, Carrillo and Abangares

Three sampling runs were conducted in the areas under study. A total of 12 samples were taken during the first sampling and Helicobacter pylori samples were identified using the glmM marker. Forty samples were taken in the second sampling and total and fecal coliforms were determined using the Most Probable Number (MPN) 
method according to Method 9221 of the Standard Methods, 21 $1^{\text {st }}$ Ed. [9]. In the third sampling, 60 samples were taken and the glmM and tumor necrosis factor-alpha inducing protein (Tipalpha TNF- $\alpha$ ) markers were determined.

Samples were analyzed at the Microbiology Laboratory of the Research \& Chemical and Microbiology Services Center-CEQIATEC. Each sample consisted of 1 liter of water from each source. In the case of chlorinated sources, residual chlorine was determined using DPD $^{\circledR}$ tablets and a HATCH chlorine comparator. Nitrocellulose membrane filters $0.45 \mu \mathrm{m}$ and a vacuum pump was used to concentrate microorganisms present in the sample.

The filter was subsequently removed using tweezers and placed inside $20 \times 150 \mathrm{~mm}$ test tubes that contained $20 \mathrm{~mL}$ of trypticase soy broth with Dent Helicobacter pylori selective supplement containing vancomycin, trimethoprim, cefsulodin and amphotericin B.

Samples were cultured under microaerophilic conditions using Campygen ${ }^{\circledR}$ for 72 hours at $35^{\circ} \mathrm{C}$. Samples were then taken from growth and molecular determinations were conducted using liquid culture media. DNA extraction from samples was done with the Promega Wizard ${ }^{\circledR}$ Genomic DNA Purification kit. Extraction was carried out as instructed by the manufacturer for Gram-negative bacteria.

DNA obtained was analyzed by $2 \%$ agarose gel electrophoresis (w/v) using TAE $1 \mathrm{X}$ (40 mM Tris-acetate, $\mathrm{pH}$ 8.0 and $1 \mathrm{mM}$ EDTA) as the running buffer at $100 \mathrm{~V}$ for 40 minutes and using Fermentas ${ }^{\circledR}$ Gene RulerTM $1 \mathrm{~kb}$ DNA ladder as the molecular weight marker.

Each PCR protocol and pair of oligonucleotides underwent preliminary evaluation as per Table 1 and was then used to evaluate the samples.

In order to evaluate glmM and TNF- $\alpha$, a total of $28 \mu \mathrm{L}$ of Fermentas PCR Master Mix (2X) were used containing $0.05 \mathrm{u} / \mu \mathrm{l}$ of Tq DNA polymerase, reaction buffer $4 \mathrm{mM} \mathrm{MgCl}, 0.4 \mathrm{mM}$ of each dNTP (dATP, dCTP, dGTP, dTTP). Also, $2.5 \mu \mathrm{l}$ of each primer (40 ng/ $\mu$ l) were used, together with $12 \mu \mathrm{l}$ molecular biology grade water and $5 \mu$ of DNA extracted by reaction for a final volume of $50 \mu l$.

Table 2 describes the thermal profile used to amplify the glmM regions and the H. pylori-specific TNF- $\alpha$.

Two positive samples were chosen and sent for molecular sequencing, was in the hands of Macrogen Corporation, Rockville, Maryland, USA. Samples were sent as per the corporation's instructions for PCR products (a single, non-degraded product and no less than $50 \mathrm{ng} / \mu \mathrm{L}$ ). Macherey-Nagel's PCR Clean-up Gel Extraction NucleoSpin ${ }^{\circledR}$ Extract II was used for PCR product cleanup.

Finally, the results obtained were used to make statistical inferences in order to establish a relationship between gastric cancer incidence rates and environmental factors specific to Costa Rica and the different areas. All variables were statistically analyzed using SPSS 16.0.

Table 1. Nucleotidic sequence and expected amplification size for the detection of $H$. pylori.

\begin{tabular}{lcl}
\hline \multicolumn{1}{c}{ Gene } & PCR product size (pb) & \multicolumn{1}{c}{ Initiator sequences 5'-3' } \\
\hline $\boldsymbol{g} \operatorname{lm} \boldsymbol{M}$ & 294 & $\begin{array}{l}\text { AAGCTTTTAGGGGTGTTAGGGGTTT } \\
\text { AAGCTTACTTTCTAACACTAACGC }\end{array}$ \\
$\begin{array}{l}\text { Tumor necrosis factor-alpha } \\
\text { inducing protein (Tipalpha TNF- } \boldsymbol{\alpha} \text { ) }\end{array}$ & 273 & $\begin{array}{l}\text { sFd 5'CACGCAAGGGGTGGATAGC3' } \\
\text { sFr-5'CGCACYAACGCAAACACTTC3' }\end{array}$ \\
\hline
\end{tabular}

Table 2. Thermal profile for PCR of glmM regions and $H$. pylori-specific $T N F-\alpha$.

\begin{tabular}{|c|c|c|c|c|}
\hline Program & Steps & Temperature $\left({ }^{\circ} \mathrm{C}\right)$ & Time & Cycles \\
\hline 1 & Initial denaturation & 94 & $2 \min (3 \min )$ & 1 \\
\hline $2(1)$ & Denaturation & 94 & $45 \mathrm{~s}$ & \\
\hline \multirow{2}{*}{$2(2)$} & $\operatorname{glm} M$ & 56 & $30 \mathrm{~s}$ & 40 \\
\hline & TNF- $\alpha$ Alignment & 60 & $20 \mathrm{~s}$ & 40 \\
\hline 2(3) & Extension & 72 & $1 \mathrm{~min}$ & \\
\hline 3 & Final extension & 72 & $7 \mathrm{~min}$ & 1 \\
\hline 4 & Storage & 4 & Whatever time is necessary & 1 \\
\hline
\end{tabular}




\section{Results}

Figure 1 is a photograph of the electrophoresis of PCR products from several positive samples of the first sampling. Controls used are also shown.

Table 3 shows the results of the samplings conducted.

In the second sampling of high incidence areas, 8 samples had residual chlorine and of these, 2 were positive using the $g \operatorname{lmM}$ marker for Helicobacter pylori with residual chlorine values of $0.3 \mathrm{mg} / \mathrm{L}$ and $0.4 \mathrm{mg} / \mathrm{L}$.

According to the results for total and fecal coliforms, only 3 of the samples contained fecal coliforms and one of these was positive using the $\operatorname{glm} M$ marker.

In the third sampling, samples that were positive for the glmMmarker were tested for the tumor necrosis factor-alpha inducing protein (Tipalpha TNF- $\alpha$ ) and 7 samples were positive, that is, $54 \%$ of $g \operatorname{lmM}$ positive samples were $T N F-\alpha$ positive.

Sequencing was conducted using two gImM gene amplified products (sample codes 25 and 12) and a Helicobacter pylori positive control strain (J99).

Macrogen reported that the nucleotide sequence of control strain J99 sent is identical (100\%) to the glmM gene of the $\mathrm{H}$. pylori J99 strain. Isolate identified as sample 25 revealed a 98\% nucleotide sequence homology with strain J99. Additionally, a 97\% homology with the UreC gene of the $H$. pylori 224A UreC and H. pylori 170A UreC strains was also observed. Isolate identified as sample 12 revealed a $97 \%$ nucleotide sequence homology with strain J99 as well as a 96\% homology with the H. pylori PP01A1 strain and a 95\% homology with the H. pylori PP03A1 strain. The latter confirms that the strains were true Helicobacter pylori isolates.

Next is a dendrogram explaining the phylogenetic relationships of the sequenced strains in a maximum parsimony tree (35:209). This phylogenetic tree has been built using informative sites. Numbers used refer to percentages and line length indicates distances and differences in DNA. Group is conserved among dendrograms,
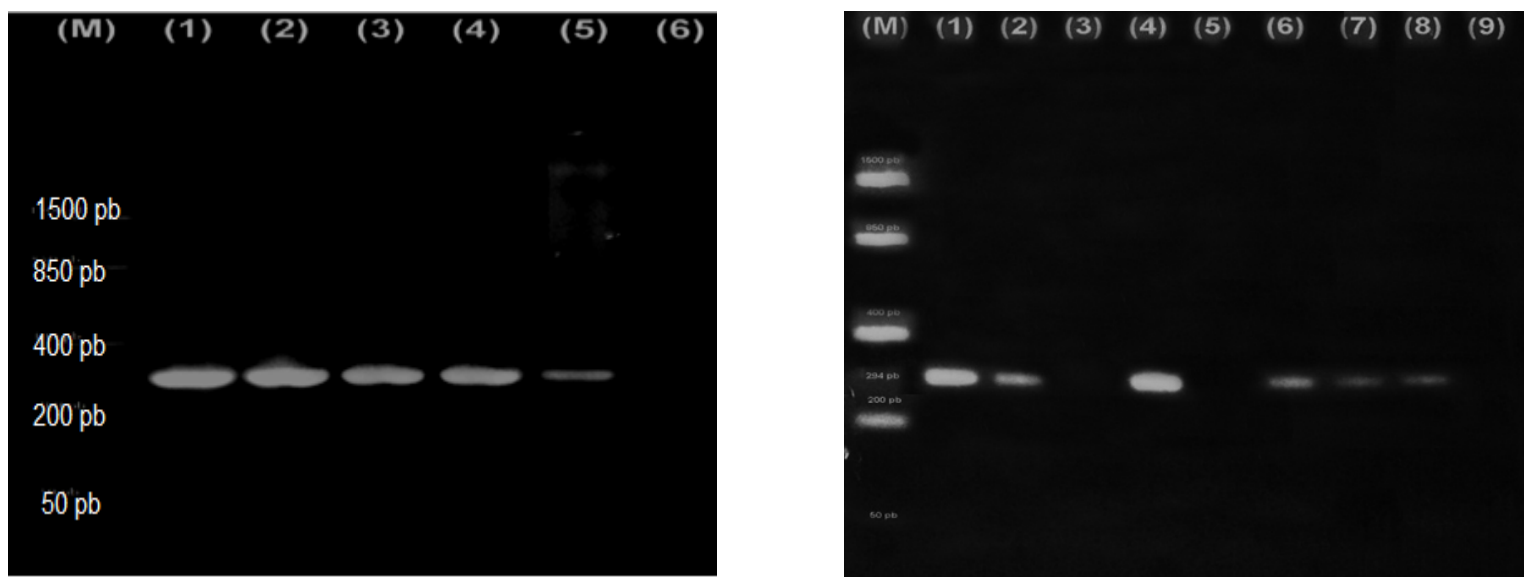

Figure 1. Visualization of PCR Products for $\operatorname{glmM}(294 \mathrm{pb})$. Left photograph-(M): FastRuler ${ }^{\mathrm{TM}}$ Low Rangemarker; (1) strain Hp 12455; (2) Strain J99; (3) H. p ATCC 51932; (4) H. pylori ATCC 700392; (5) Sample +; (6) Control: water. Right photograph: (1) H. pylori ATCC 700392; (2) H. pylori ATCC 51932; (3) E. coli; from (4) to (8) Samples +; (9) Control: water.

Table 3. Summary of results by sampling in areas of high and low incidence.

\begin{tabular}{ccc}
\hline Sampling/samples & High Incidence Areas Positive/Total & Low Incidence Areas Positive/Total \\
\hline 1st (12) & $6 / 12$ & ND \\
2nd (40) & $12 / 30$ & $3 / 10$ \\
3rd (60) & $10 / 30$ & $3 / 40$ \\
Total (112) & $29 / 72$ & $\mathbf{7 , 5}$ \\
Positive Total \% & $\mathbf{3 9}$ & \\
\hline
\end{tabular}

ND: Not done 
which shows that the subgroup is true and not random. All strains reported for the glmM gene were selected.

As shown in Figure 2, a total of 208 base pair sequences of the gene were used.

Once the second sampling was finalized, differences between areas of high and low incidence were evident. Geophysical, environmental and water management data was then collected in order to establish significant differences and be able to relate the presence of the bacteria in the population's drinking water to the incidence rate for gastric cancer in those areas under study.

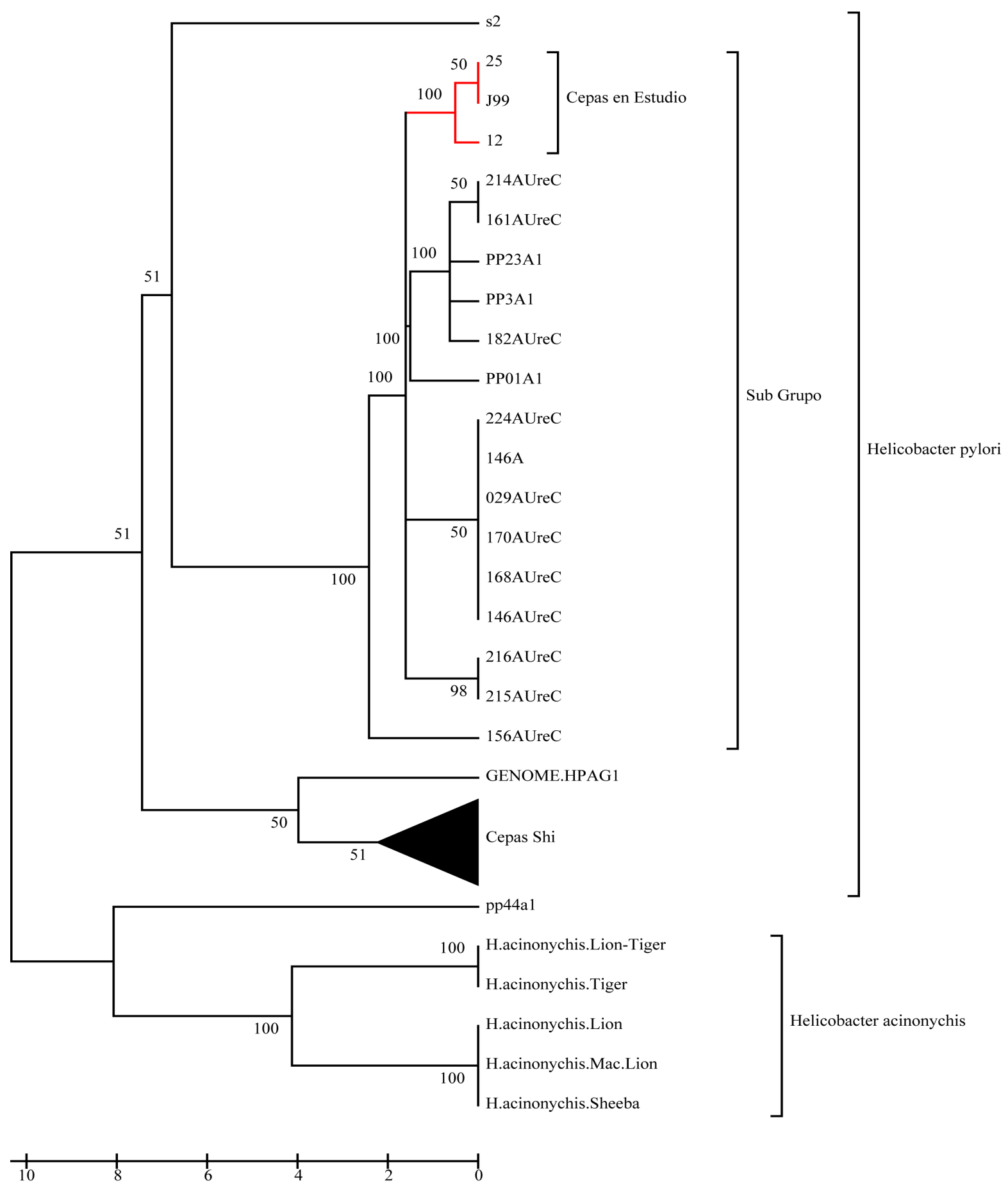

Figure 2. Maximum parsimony tree showing the phylogenetic relationship of the sequenced strains under study (red), by glm $M$ gene. 
One of the initial findings had to do with differences in altitude (masl) and the incidence rate for gastric cancer. These differences were marked (correlation coefficient $=0.86)($ Figure 3$)$.

Comparisons were then made between incidence rate of gastric cancer in the cantons under study and altitude, environmental temperature, water source and operator of aqueduct supplying water to the population. All variables were statistically analyzed using SPSS 16.0 and significant and important correlations were established using Pearson's correlation analysis as follows:

- Incidence of gastric cancer and altitude: 0.867

- Incidence of gastric cancer and environmental temperature: -0.853

- Incidence of gastric cancer and water source: 0.651 .

- Linear regression coefficient between incidence of gastric cancer and temperature: $\mathrm{R}^{2}=0.728$.

Fisher's exact test was used to determine interdependence between incidence level (low and high) and aqueduct operator. Evidence obtained was sufficient to accept the null hypothesis of interdependence between both variables $(\mathrm{p}<0.05)$.

\section{Discussion}

The isolation and cultivation of Helicobacter pylori from drinking water samples was possible using liquid culture media and a Millipore filter to support growth. This finding coincides with the inability to recover bacteria by direct culture from water samples as reported by Oliver, 2005 [10] and Adams, 2003 [11]. By means of phase contrast microscopy, it was determined that the bacteria did grow in a liquid culture media; however, lack of turbidity prevented this growth from being observed and therefore, bacteria exhibited intermediate to coccoid morphology.

Statistical analysis revealed the existence of a relationship between incidence rate of gastric cancer, geographic altitude, environmental temperature and water source and this relationship is not random (95\% confidence interval). Additionally, there is also a relationship between the aqueduct operator and incidence of gastric cancer in both areas studied. Therefore, the aqueduct operator could play a very important role in this problem. These are all factors that can be related to $H$. pylori survival in the environment.

This study also investigated the new marker for the tumor necrosis factor-alpha inducing protein (Tipalpha TNF- $\alpha$ ) gene, which was found in $54 \%$ of the glmM positive strains of the third sampling. This is a very important finding due to the fact that this is a new pathogenicity marker that has never been used in environmental strains [12]-[14].

Immunomagnetic antibodies were initially used as reported by Lu et al. [15]. It was quickly determined, however, that the filter adhesion strategy was much more efficient, cheaper and quicker and therefore, this technique

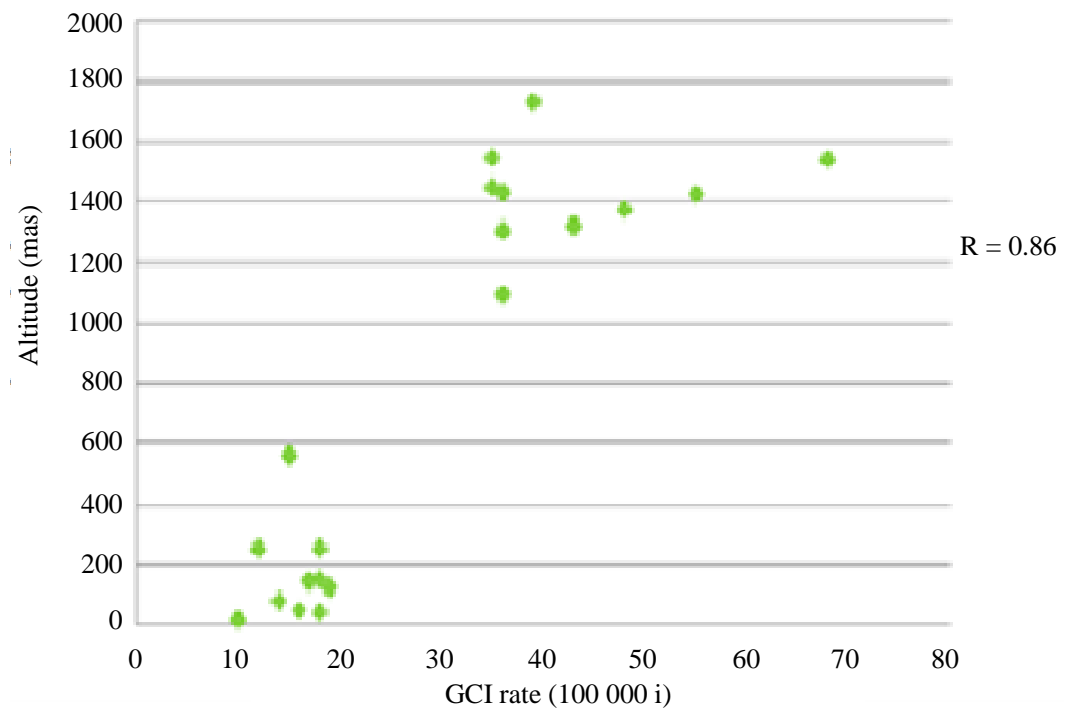

Figure 3. Correlation between Altitude and gastric cancer incidence rate for the cantons under study. 
was used with all samples.

Statistics available to date in Costa Rica for gastric cancer reveal no clear downward trend in incidence among men and women. The incidence rate did exhibit a downward trend until 2002; however, incidence increased in 2003. Costa Rica's National Tumor Registry has not offered any new data after 2003.

It is not possible to definitely assert that the incidence of gastric cancer in Costa Rica is decreasing. This, therefore, leads to the belief that the intrinsic influence that selectively increases the incidence rate is still in the environment and consequently in the population.

This study succeeded in isolating Helicobacter pylori from drinking water. Helicobacter pylori studies have generally been conducted using direct or indirect samples from human beings. Few studies report finding $H$. pylori in water, let alone in the population's drinking water. It is important to highlight that the study conducted by Hegarty [16] is the only one dealing with surface water and he is the first to report no significant correlation between Helicobacter pylori and E. coli. Additionally, Lu et al. are the only ones to have sequenced strains from residual water [15].

According to Azevedo et al. [17] when Helicobacter pylori adheres to a surface quorum sensing activation begins and biofilm formation mechanisms are activated. Azevedo et al. [17]-[19] have worked with biofilms on piping systems and storage tanks and believe this is how Helicobacter pylori can still be viable in water.

It is in this manner that $H$. pylori protects itself from an environment "perceived" as aggressive. This suggests that $H$. pylori bacteria is not found freely in water of natural origin; it is adhered (sessile). In this study, $H$. pylori was recovered from the water in its bacillary form using a new culture method.

Biofilm creation was the result of using nitrocellulose filters and this strategy was used to cultivate biofilms in drinking water thus demonstrating that this was a probable means of transmission of the bacteria.

Detection was possible with glmM molecular markers. Along the same lines, several authors such as Jang-Jih Lu et al. [20] believe this gene to be the most sensitive and specific marker to detect the presence of Helicobacter pylori. They found that there were false-positive results for the $16 S$ rRNA gene in gastric biopsies. These findings are in agreement with the findings of Shahamat et al. [21]. These inconveniences, however, might also stem from primer design.

Environmental conditions at the time when sampling was conducted had a direct impact on detection. This has been mentioned by several authors such as Azevedo [22] and Benson [23]. This finding is indicative of the transitory nature of water source contamination, particularly recent precipitations. These authors, however, do not discuss why this occurs.

Bani Hani et al. [24] established a relationship between environmental factors (such as atmospheric pressure and environmental temperature) and differences in $H$. pylori infection among people. In short, in agreement with this study, Bani Hani et al. found higher prevalence in high altitude areas.

Regarding water quality, no relationship was found between fecal coliforms and presence of $H$. pylori. In this regard, Braganca et al. [25] report that $H$. pylori is more resistant to chlorination than $E$. coli. This has also been reported by Baker and Hegarty [26]. Additionally, Hegarty point out that the lack of correlation between the presence of $H$. pylori DNA in drinking water and the ocurrence of $E$. coli reveals that the presence of the latter is not indicative of water potability (Hegarty, 1999). Mazari et al. [27] have warned that treated residual water is not necessarily free from $\mathrm{H}$. pylori and therefore, constitutes a serious public health risk because of cross contamination.

In this study, areas with low incidence of gastric cancer have conditions that could be related to a reduced presence of Helicobacter pylori such as the fact that $90 \%$ of the population's water supply has undergone chlorination for many years (a practice that dates back to the 60's and 70's) in addition to geomorphological and physical-chemical soil characteristics that are less favorable for the development of Helicobacter pylori, areas that are proportionally drier throughout the year and a $\mathrm{pH}$ that is comparatively higher than the one found in high incidence areas.

With regard to the incidence of gastric cancer in Costa Rica and its relationship with soil properties, Sierra et $a l$. in 1983 [28] warned over the existence of statistically significant correlations among incidence rate and acidity or low $\mathrm{pH}$, iron, potassium and zinc in soil. The effect of soil $\mathrm{pH}$ had already been studied by Hirayama in 1971 [28], while Tromp in 1981 [28] referred to the possibility of a multifactorial influence in soil.

The dissolved organic matter content of soil increases with humidity and lower temperatures [29]. Azevedo points out that the world's cold regions have higher infection rates and that transmission is most likely to occur during the rainy season [28]. 
Costa Rica has a comparatively high water supply all year round, especially in those areas of high incidence of gastric cancer. This is found to be particularly relevant because this means that local governments are in charge of managing their own water resources and therefore, adequate controls are not always in place resulting in water quality variations.

This study proposes the waterborne transmission of Helicobacter pylori, which would explain the decrease in Helicobacter pylori colonization of humans in developed countries, where strict drinking water quality parameters are applied.

\section{Acknowledgements and Disclosures}

Financial support from the Instituto Tecnológico de Costa Rica and the Costa Rican Water and Sewer Institute is gratefully acknowledged.

We would also like to give special thanks to Dr. Sergio Con Chin for taking the time and effort necessary to revise this article; and to Dr. Fernando García for supervising this doctoral thesis.

We are also grateful to students Gustavo López, Jimena Orozco and Karina Barboza for their assistance.

Conflict of Interest Statement: The authors declare that there is no conflict of interest.

\section{References}

[1] Fox, J., Beck, P., Dangler, C., Whary, M., Wang, T., Shi, H. and Nagler, C. (2000) Concurrent Enteric Helminth Infection Modulates Inflammation and Gastric Immune Responses and Reduces Helicobacter-Induced Gastric Atrophy. Nature Medicine, 6, 536-542. http://dx.doi.org/10.1038/75015

[2] American Cancer Society. Cancer Facts and Figures for Hispanics/Latinos 2006-2008. Atlanta, Georgia.

[3] Con, S.A., Takeuchi, H., Valerin, A.L., Con-Wong, R., Con-Chin, G.R., Con-Ching, V.G., Nishioka, M., Mena, F., Brenes, F., Yasuda, N., Araki, K. and Sugiura, T. (2007) Diversity of Helicobacter pylori cagA and vacA Genes in Costa Rica: Its Relationship with Atrophic Gastritis and Gastric Cancer. Helicobacter, 12, 547-552. http://dx.doi.org/10.1111/j.1523-5378.2007.00534.x

[4] (2012) World Health Organization. International Agency for Research on Cancer. Agents Classified by the IARC Monographs, Volumes 1-104, 2012.

[5] Ding, S.Z., Goldberg, J.B. and Hatakeyama, M. (2010) Helicobacter pylori Infection, Oncogenic Pathways and Epigenetic Mechanisms in Gastric Carcinogenesis. Future Oncology, 6, 851-862. http://dx.doi.org/10.2217/fon.10.37

[6] Ferlay, J., Shin, H.R., Bray, F., Forman, D., Mathers, C. and Parkin, D.M. (2010) Estimates of Worldwide Burden of Cancer in 2008: GLOBOCAN 2008. International Journal of Cancer, 127, 2893-2917. http://dx.doi.org/10.1002/ijc.25516

[7] Vargas, R., Ortiz, A. and Muñoz, G. (2007) Incidencia y Mortalidad del cáncer en Costa Rica 1995-2005. Ministerio de Salud. Dirección Vigilancia de la Salud Unidad de Estadística-Registro Nacional de Tumores..

[8] Occhialini, A., Marais, A. and Alm, R. (2000) Distribution of Open Reading Frames of Plasticity Region of Strain J99 in Helicobacter pylori Strains Isolated from Gastric Carcinoma and Gastritis Patients in Costa Rica. Infection and Immunity, 68, 6240-6249. http://dx.doi.org/10.1128/IAI.68.11.6240-6249.2000

[9] Eaton, A. (2005) Standard Methods for the Examination Water and Wastewater. 21st Edition, Washington, D.C., American Public Health Association (APHA), American Water Works Association (AWWA), and the Water Environment Federation (WEF). 2005. 9.1-9.164.

[10] Oliver, J. (2005) The Viable but Nonculturable State in Bacteria. The Journal of Microbiology, 43, 93-100.

[11] Adams, B., Bates, T. and Oliver, J. (2003) Survival of Helicobacter pylori in a Natural Freshwater Environment. Applied and Environmental Microbiology, 69, 7462-7466. http://dx.doi.org/10.1128/AEM.69.12.7462-7466.2003

[12] Cheng, P., Shi, R.H., Zhang, H.J., Yu, L.Z., Zhang, G.X. and Hao, B. (2008) Effects of Tumor Necrosis Factor-Alpha Inducing Protein-Alpha Secreted by Helicobacter pylori on Human Gastric Epithelial Cells. National Medical Journal of China, 88, 1528-1532.

[13] Watanabe, T., Tsuge, H., Imagawa, T., Kise, D., Hirano, K., Beppu, M., Takahashi, A., Yamaguchi, K., Fujiki, H. and Suganuma, M. (2010) Nucleolin as Cell Surface Receptor for Tumor Necrosis Factor-Alpha Inducing Protein: A Carcinogenic Factor of Helicobacter pylori. Journal of Cancer Research and Clinical Oncology, 136, 911-921. http://dx.doi.org/10.1007/s00432-009-0733-y

[14] Cinghu, S., Sivasithambaram, N. and Venkatraman, J. (2011) Molecular and Histological Evaluation of Tumor Necrosis Factor-Alpha Expression in Helicobacter pylori-Mediated Gastric Carcinogenesis. Journal of Cancer Research and Clinical Oncology, 137, 577-583. http://dx.doi.org/10.1007/s00432-010-0921-9 
[15] Lu, Y., Redlinger, T., Avitia, R., Galindo, A. and Goodman, K. (2002) Isolation and Genotyping of Helicobacter pylori from Untreated Municipal Wastewater. Applied and Environmental Microbiology, 68, 1436-1439. http://dx.doi.org/10.1128/AEM.68.3.1436-1439.2002

[16] Hegarty, J., Dowd, H. and Baker, K. (1999) Occurrence of Helicobacter pylori in Surface Water in the United States. Journal of Applied Microbiology, 87, 697-701. http://dx.doi.org/10.1046/j.1365-2672.1999.00912.x

[17] Azevedo, N., Pacheco, A., Vieira, M. and Keevil, C. (2004) Nutrient Shock and Incubation Atmosphere Influence Recovery of Culturable Helicobacter pylori from Water. Applied and Environmental Microbiology, 70, 490-493. http://dx.doi.org/10.1128/AEM.70.1.490-493.2004

[18] Azevedo, N., Pacheco, A., Keevil, C. and Vieira, M. (2006) Adhesion of Water Stressed Helicobacter pylori to Abiotic Surfaces. Journal of Applied Microbiology, 101, 718-724. http://dx.doi.org/10.1111/j.1365-2672.2006.03029.x

[19] Azevedo, N., Pinto, A., Reis, N., Vieira, M.J. and Keevil, C. (2006) Shear Stress, Temperature, and Inoculation Concentration Influence the Adhesion of Water-Stressed Helicobacter pylori to Stainless Steel 304 and Polypropylene. Applied and Environmental Microbiology, 72, 2936-2941. http://dx.doi.org/10.1128/AEM.72.4.2936-2941.2006

[20] Lu, J.J., Perng, C.L., Shyu, R.Y., Chen, C.H., Lou, Q., Chong, S.K. and Lee, C.H. (1999) Comparison of Five PCR Methods for Detection of Helicobacter pylori DNA in Gastric Tissues. Journal of Clinical Microbiology, 37, 772-774.

[21] Shahamat, M., Alavi, M., Watts, J., González, J., Sowers, K., Maeder, D. and Robb, F. (2004) Development of Two PCR-Based Techniques for Detecting Helical and Coccoid Forms of Helicobacter pylori. Journal of Clinical Microbiology, 42, 3613-3619. http://dx.doi.org/10.1128/JCM.42.8.3613-3619.2004

[22] Azevedo, N., Guimares, N., Figuereido, C., Kevil, C. and Vieira, M.J. (2007) A New Model for the Transmission of Helicobacter pylori: Role of Environmental Reservoirs as Gene Pools to Increase Strain Diversity. Critical Reviews in Microbiology, 33, 157-169. http://dx.doi.org/10.1080/10408410701451922

[23] Benson, J., Fode-Vaughan, K. and Collins, M. (2004) Detection of Helicobacter pylori in Water by Direct PCR. Letters in Applied Microbiology, 39, 221-225. http://dx.doi.org/10.1111/j.1472-765X.2004.01555.X

[24] Bani-Hani, K. and El-Migdadi, F. (2005) A Comparative Study of the Prevalence of Helicobacter pylori between the Inhabitants of Areas of Different Barometric Pressure. The Internet Journal of Gastroenterology, 3.

[25] Braganca, S. (2005) Detection of Helicobacter pylori in Biofilms Formed in a Real Drinking Water Distribution System Using Peptide Nucleic Acid Fluorescence in Situ Hybridization. In: McBain, A., Allison, D., Pratten, J., Spratt, D., Upton, M. and Manchester, J., Eds., Biofilms: Persistence and Ubiquity, Biofilm Club, Manchester.

[26] Baker, K., Hegarty, J., Redmond, B., Reed, N. and Herson, D. (2002) Effect of Oxidizing Disinfectants (Chlorine, Monochloramine, and Ozone) on Helicobacter pylori. Applied and Environmental Microbiology, 68, 981-984. http://dx.doi.org/10.1128/AEM.68.2.981-984.2002

[27] Mazari, M., López, Y., Castillo, G., Ponce, S. and Cravioto, A. (2001) Helicobacter pylori and Other Enteric Bacteria in Freshwater Environments in Mexico City. Water Science and Technology, 32, 458-476.

[28] Sierra, R. and Barrantes, R. (1983) Aspectos ecológicos del cáncer gástrico en Costa Rica. Revista de Biología Tropical, 3, 11-17.

[29] Méndez, E., Cruz, G. and Ángeles, E. (2010) Hidrólisis de N-Orgánico y Liberación de $\mathrm{NH}_{4}^{+}$Mediante Actividad Ureasa en Suelos Forestales de Áreas Naturales Protegidas. Laboratorio de Edafología y Fisiología de la Nutrición Vegetal, FES Zaragoza, UNAM, Boletín CAMAFU, Online. 
Scientific Research Publishing (SCIRP) is one of the largest Open Access journal publishers. It is currently publishing more than 200 open access, online, peer-reviewed journals covering a wide range of academic disciplines. SCIRP serves the worldwide academic communities and contributes to the progress and application of science with its publication.

Other selected journals from SCIRP are listed as below. Submit your manuscript to us via either submit@scirp.org or Online Submission Portal.
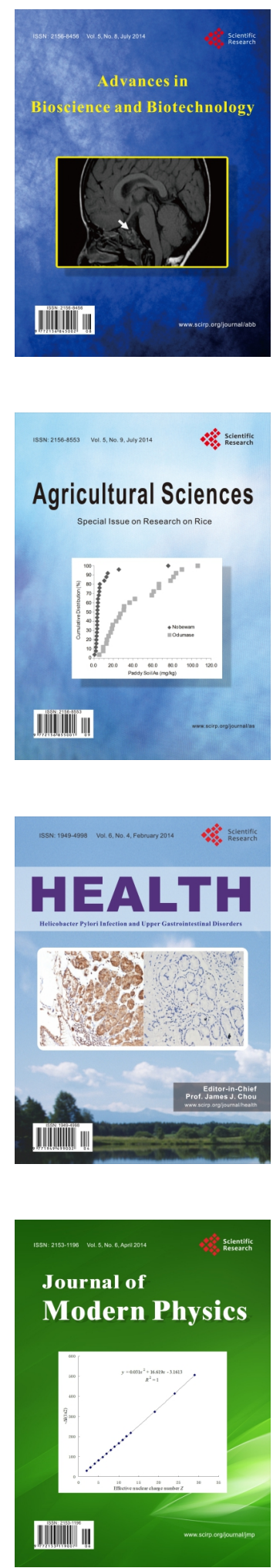
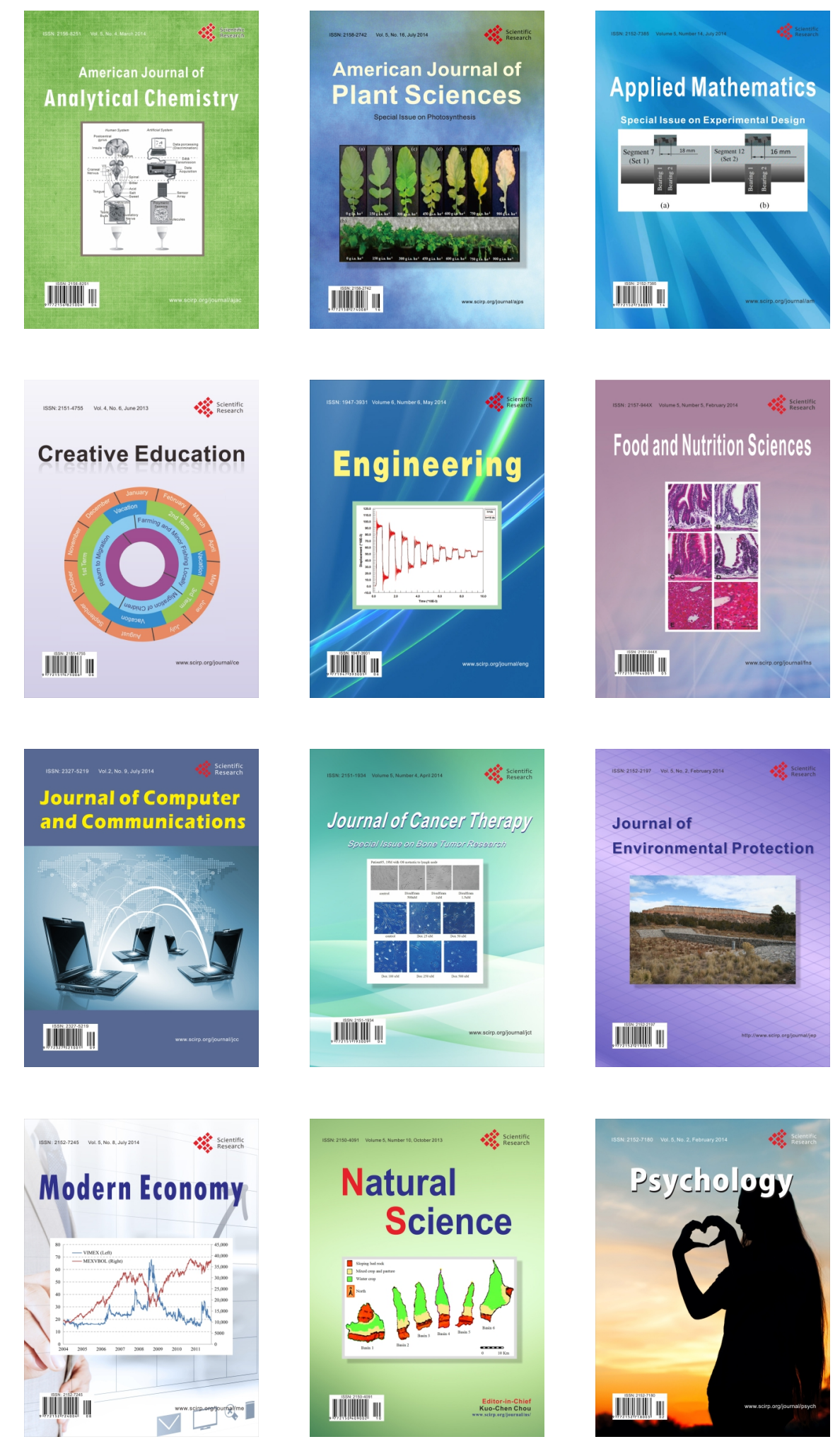